\title{
Rapid Vegetative Propagation Method for Carob
}

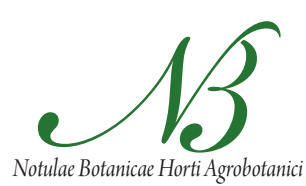

Clui-Napoca

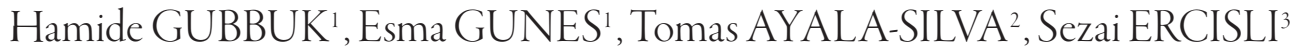 \\ ${ }^{1}$ Akdeniz University, Faculty of Agriculture, Department of Horticulture, Antalya 07058, Turkey; gubbuk@akdeniz.edu.tr \\ ${ }^{2}$ National Germplasm Repository System, Subtropical Horticulture Research Station, Miami, FL, USA \\ ${ }^{3}$ Ataturk University, Agricultural Faculty, Department of Horticulture, Erzurum 25240, Turkey
}

\begin{abstract}
Most of fruit species are propagated by vegetative methods such as budding, grafting, cutting, suckering, layering etc. to avoid heterozygocity. Carob trees (Ceratonia siliqua L.) are of highly economical value and are among the most difficult to propagate fruit species. In the study, air-layering propagation method was investigated first time to compare wild and cultivated ('Sisam') carob types. In the experiment, one year old carob limbs were air-layered on coco peat medium by wrapping with aluminum foil and polyethylene film. Initial roots were observed after three months of treatment and the well rooted limbs were cut-off after six months of treatment. Root length, diameter, and the number of roots were recorded on treated shoots and the rooted shoots were transferred into soil. As a result, it has been found that air-layering is successful in carob. This method is more labor intensive and thus it is recommend the method only for genetically important carob types propagation.
\end{abstract}

Keywords: air layering, Ceratonia siliqua L., limbs, potted plant, rooting

\section{Introduction}

Carob (Ceratonia siliqua L.) belongs to the Fabaceae family (subfamily Caesalpinioideae). It is a long lived fruit species and forms an important part of Mediterranean vegetation (Ciccarese et al. 1988; Batlle and Tous 1997). The species normally has dioeciously flower biology and it is an evergreen tree up to $10 \mathrm{~m}$ in height (Ortiz et al. 1995).

It tolerates adverse conditions, drought, and alkali soils and is extremely tolerant to heat and dry atmosphere. They are used naturally against soil erosion and land reclamation in most of Mediterranean areas (Janick and Paull, 2008).

Carob is well known in the Mediterranean countries for its ornamental, nutritional and medicinal value. Its pods (legumes) have traditionally been used for animal and human food ( Batlle and Tous, 1997). Annual world production of carob pods mainly from Mediterranean countries including Spain, Italy and Portugal reaches 180.000 tons (Anonymous, 2009). As an origin country of carob, Turkey produces around 14.000 tons carob annually (Anonymous, 2009).

Carob may be propagated by generative (seed) and vegetative (budding, veneer grafting, cutting) methods. However, carob seeds are difficult to germinate. The seed coat is extremely hard and not ready to absorb water (Coit, 1951). Generative propagated carob seedlings are used as rootstocks for grafting. In addition, carob rootstocks are raised from open-pollinated carob seeds and these seedling rootstocks vary widely in vigor, growth habit and cold resistance (Batlle and Tous, 1997). No commercial rootstock trials have been carried out on cultivars and no rootstock selections are available for carob. The seedling rootstocks are budded on one year seedlings after germination in the nursery or two years after planting in the orchard (Batlle and Tous, 1997). Vegetative propagation by cuttings is not yet commercially available (Batlle and Tous, 1997). Carob cuttings has also been described by Lee et al. (1977) and Hartmann and Kester (1983) as one of the most difficult species to root. Therefore, grafting is the main solution for continue vegetative propagation. However, it takes nearly more than two years to obtain grafted nursery material. In this way, traditional carob propagation has been achieved by grafting seedlings with female buds of chosen productive trees (Batlle and Tous, 1997). The use of micropropagation techniques can be the solution to faster propagation but the response of the explants during the establishment phase is however, seasonal dependent and cannot be applied in all nurseries (Romano et al., 2002). Therefore air-layering may be a reliable and easy means of propagation in carob which is difficult-to-root with other methods. This method has been applied in economically important woody plants (Pio et al., 2007; Gamlath et al., 2010; Sasso et al., 2010). The application of air-layering may provide the retention of desirable characteristics and the ability to mass production of identical plants quickly and efficiently.

Air-layering is mainly used for woody plants; in literature searched, it has been not found any reports of air-layering on carob and moreover, there are no reports of carob plants from air-layering being successfully established in the field.

The present study reports on a novel propagation technique of carob using the air-layering method. In this method the reaserch aimed to eliminate rootstocks problems of this species. 
252

\section{Materials and methods}

The study was conducted in March 2009 in Antalya province of Turkey. 'Sisam' (cultivated type) and wild type carob (Ceratonia siliqua L.) were used as experimental material. Healthy and well developed branches were selected from naturally grown trees in the field. The treatments were done on one year old shoots, 12 shoots per type, on these selected branches. Coco peat was used as the rooting medium for shoots (Sahin et al., 2002). Two encircling cuts were done on each shoot and a ring of bark $(2.5-3 \mathrm{~cm})$ was removed by knife to expose the inner woody tissue (Fig. 1a).

Commercial coco peat was wetted one day before use, washed three times and then squeezed to remove excess water. The encircled area was covered with a moist coco-peat

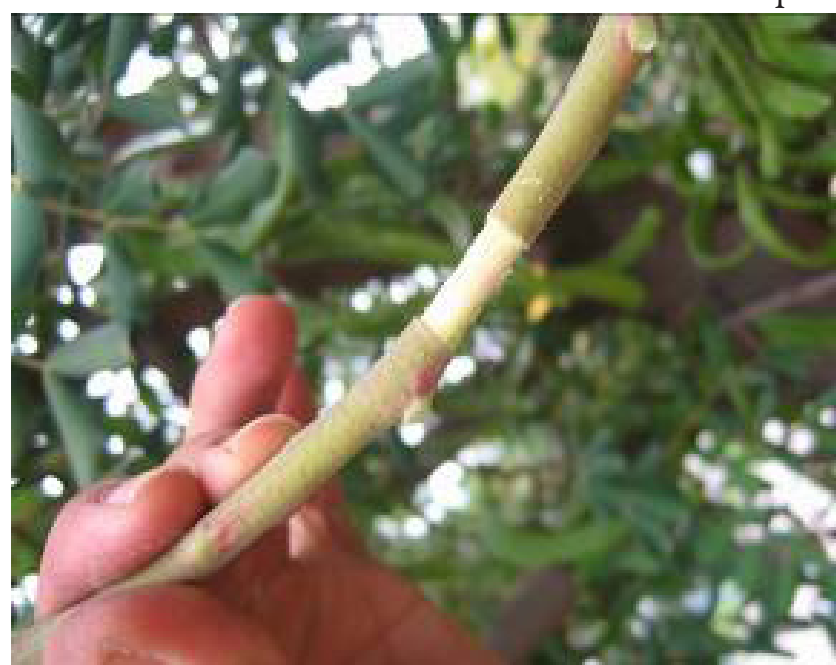

a: Preparation of one year shoot of carob for air layering under partial shade. The potting medium consisted of 2:1 peat: perlite medium. The plants were transferred to the field after two-three months.

\section{Results and discussion}

The results of treatments on main root number, diameter and length, secondary root number, diameter and length among wild and cultivated carob types are given in Tab. 1. Newly roots appeared after 3 months of treatment (Fig. 2a). However, final observations were taken at 6 months, when the air layers were removed from the mother plants (Fig. $2 \mathrm{~b}$ and $2 \mathrm{c}$ ).

The wild type demonstrated higher main root number, main root length and secondary root number than 'Sisam' (Tab. 1). The main root numbers varied from 6.42 (wild

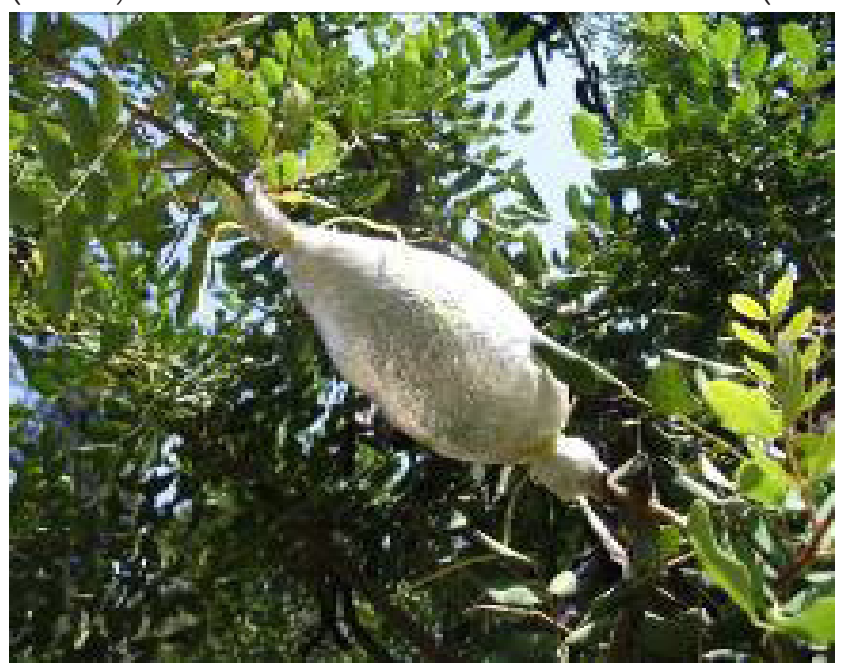

b: Wrapped shoot with coco-peat, aluminum foil and bag

Fig. 1. Preparation of shoot and wrapping

medium and kept in position by wrapping with aluminum foil and polyethylene film (Fig. 1b) and covered for about six months. Initial roots were observed after three months of treatment and when large quantities of roots were observed through the polyethylene film, the branch with its roots was severed from the parent tree and potted up for later planting. The roots (main and secondary) number and root diameter was recorded on these air layers. Air layers having at least one root $(1 \mathrm{~mm})$ were classified as rooted. Data were then subjected to statistical analysis. Mean and standard error were calculated for all the parameters. Rooted plants were transferred to black plastic bags (11×20 cm dimension) and placed in the greenhouse type) to 5.25 (cultivated type) (Tab. 1). Secondary root number was significantly higher in wild type (45.60) than cultivated one (36.58). Secondary roots are shown in Fig. 2c. Main root diameter was recorded as $1.29 \mathrm{~mm}$ for wild and $1.39 \mathrm{~mm}$ for cultivated type, respectively. On the other hand, no significant differences were found in terms of secondary root diameter (Tab. 1). The main root length was higher for wild type than cultivated type. However, the secondary root length was higher for the cultivated type than the wild type (Tab. 1).

The rooted shoots (Fig. 3a) easily adapted in the plastic bags (Fig. 3b) when separated from the mother plants.

Tab. 1. Some root characteristics of wild and cultivated carob air-layered shoots

\begin{tabular}{ccccccc}
\hline Types & $\begin{array}{c}\text { Main root } \\
\text { number }\end{array}$ & $\begin{array}{c}\text { Secondary } \\
\text { root number }\end{array}$ & $\begin{array}{c}\text { Main root } \\
\text { diameter }(\mathrm{mm})\end{array}$ & $\begin{array}{c}\text { Secondary root } \\
\text { diameter }(\mathrm{mm})\end{array}$ & $\begin{array}{c}\text { Main root length } \\
(\mathrm{cm})\end{array}$ & $\begin{array}{c}\text { Secondary root } \\
\text { length }(\mathrm{cm})\end{array}$ \\
\hline $\begin{array}{c}\text { Wild } \\
\text { Cultivated }\end{array}$ & $6.42 \pm 2.00$ & $45.60 \pm 9.70$ & $1.29 \pm 0.05$ & $0.69 \pm 0.17$ & $5.95 \pm 1.21$ & $1.81 \pm 0.73$ \\
$($ Sisam) & $5.25 \pm 2.00$ & $36.58 \pm 11.54$ & $1.39 \pm 0.17$ & $0.68 \pm 0.13$ & $5.50 \pm 0.94$ & $2.07 \pm 0.40$ \\
\hline
\end{tabular}




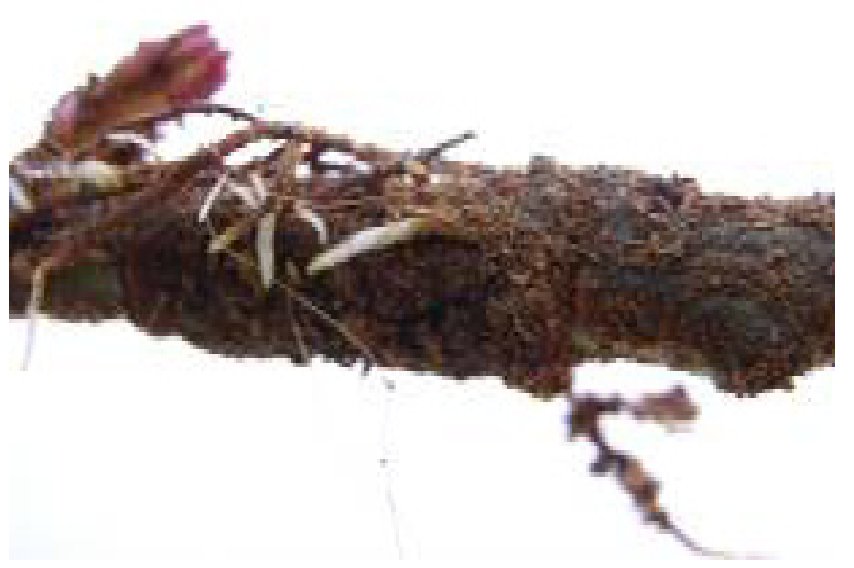

a: Newly formed roots after three months

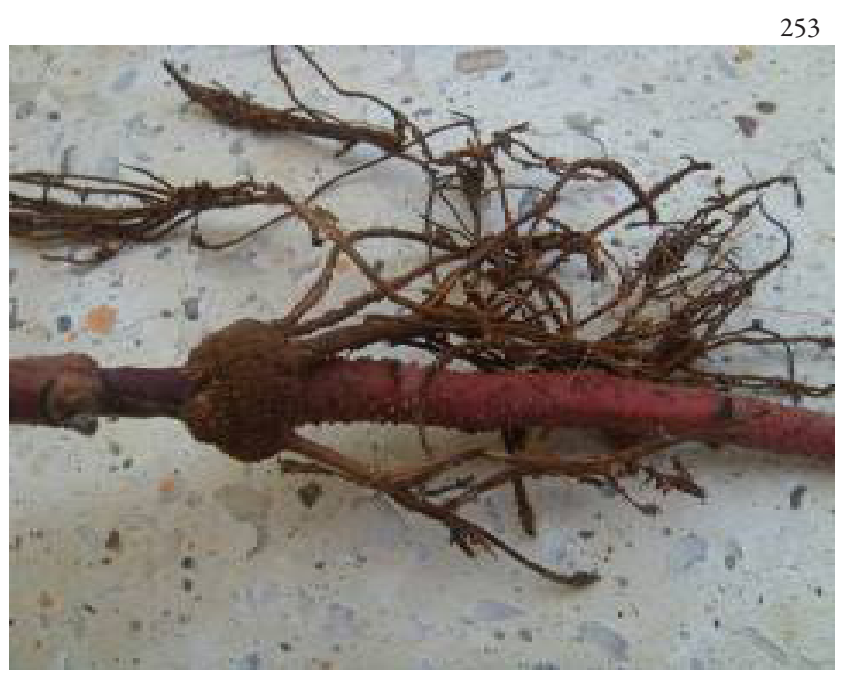

b: Well developed roots after six months

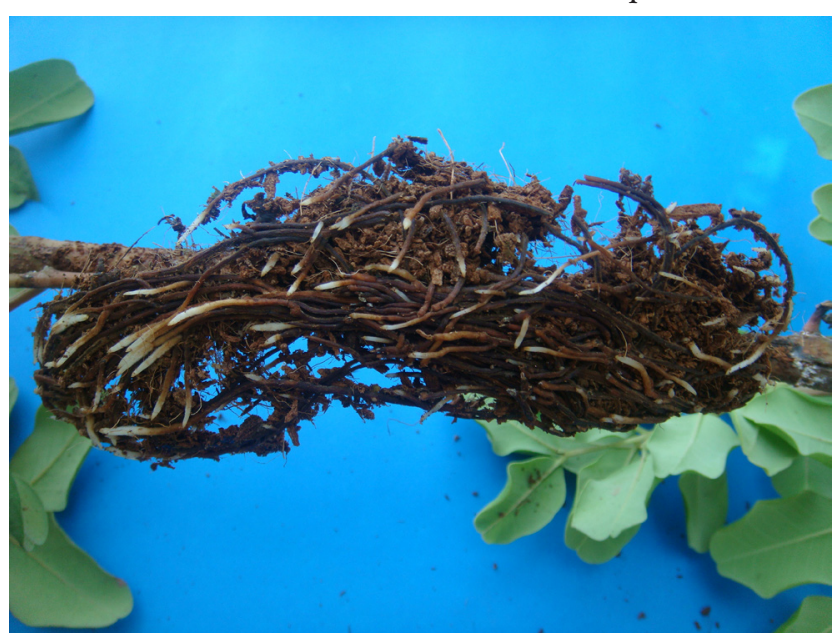

c: Secondary root development

Fig. 2. Different stage of root development

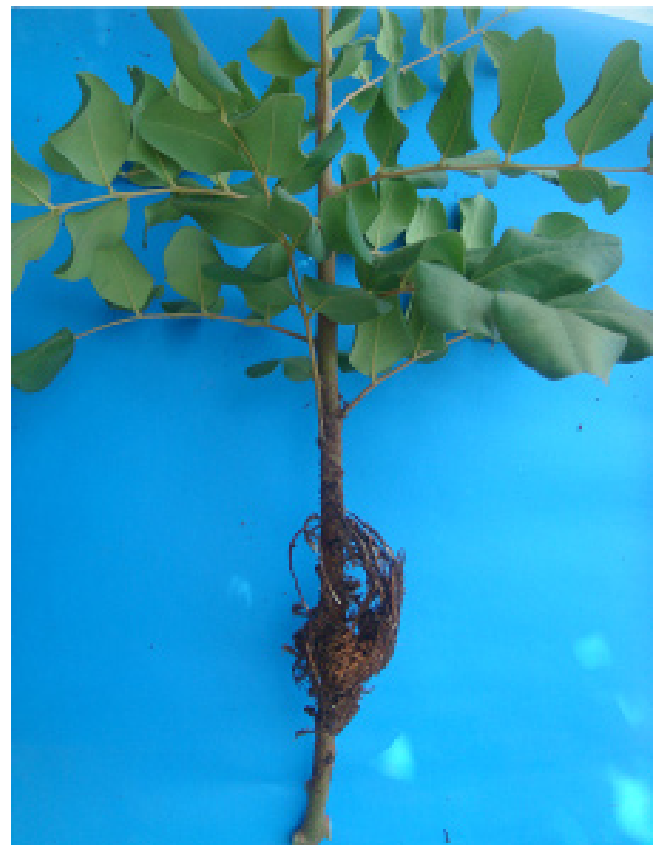

a: A rooted seedling ready for transferring to soil

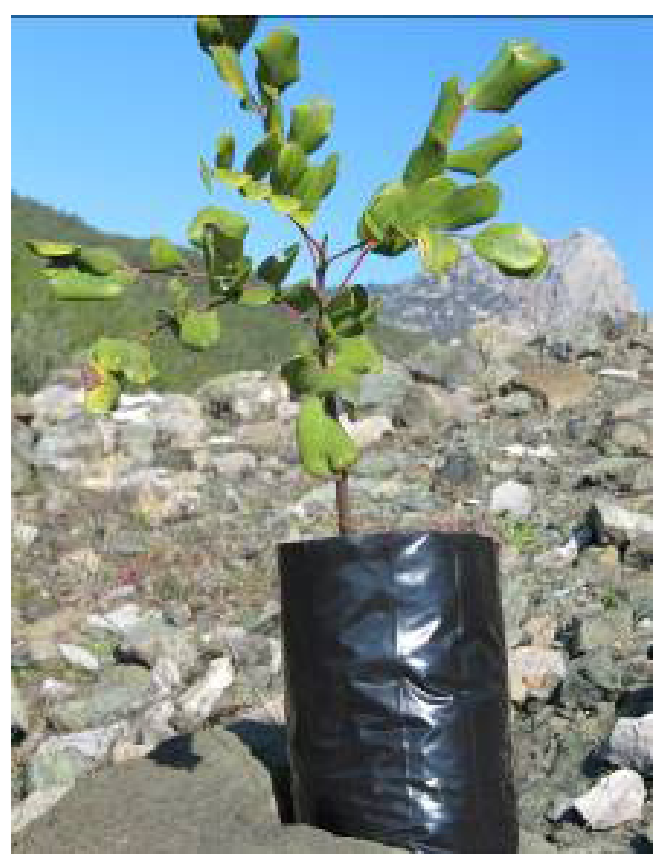

b: Well established carob seedling in plastic bag

Fig. 3. Rooted and well established carob seedling 
254

The results from this study indicated that propagation of carob trees by air layering is successful. Previously, this method has been successfully applied in other fruit trees for example waterapples (Paul and Aditi, 2009), cashewnuts (Ghost et al., 1994) and figs (Gamlath et al., 2010). Variations in rooting behavior of wild and cultivated types can be due to fluctuations in the availability of sugars as a result of differential activities of hydrolyzing enzymes, which are the principal source of metabolic energy required for cell activities during root initiation (Nanda, 1975). The future direction is to investigate the use of different plant growth regulators with air-layering. It will also use more genotypes in future studies in air-layering.

\section{Conclusions}

In conclusion, propagation of carob trees by air layering is successful. However, if it is compare to grafting, air-layering is more labor intensive. Therefore, air-layering could be preferred to propagate promising carob types in a short period.

\section{Acknowledgements}

The work supported by COST 866 (TÜBİTAKTOVAG 106O832) and the Scientific Research Projects Coordination Unit of Akdeniz University. The authors thank Professor Dr. Ahmed Ait-Oubahou from Institut Agronomique et Vétérinaire Hassan II, Agadir, Morocco and Mr. Dale Stennet, Subtropical Horticulture Research Station, Miami, Florida, USA for the critical review of the manuscript.

\section{References}

Anonymous (2009). http://www.fao.org.

Battle I, Tous J (1997). Carob tree. Ceratonia siliqua L. Promoting the conservation and use of underutilized and neglected crops. 17. Institute of Plant Genetics and Crop Plant Research. Gatersleben/IPGRI, Rome, Italy.

Ciccarese L, Piccini C, Piotto B, Scalambretti R (1988). Carob tree: an important resource in Mediterranean areas. Agenzia Nazionale per la Protezione dell'Ambiente (ANPA). Roma, Italy.
Coit JE (1951). Carob or St. John's Bread. Journal Economy Botany 5:82-96.

Gamlath M, Abeywickrama K, Wickramarachchi S (2010). Root growth promotion of Ficus species during air-layering. Ceylon Journal of Science (Biological Sciences) 39(1):4551.

Ghosh DK, Bandopadhyay AK, Sen SK (1994). Response of auxinic and non-auxinic chemicals on rooting of cashewnut (Anacardium occidentale L.) air-layers. Environmental and Ecology 12(1):276-277.

Hartmann HT, Kester DE (1983). Plant Propagation, Principles and Practices: In: (4 ${ }^{\text {th }}$ edn. Ed.), Prentice Hall, New York, USA, p. 265-268.

Janick J, Paull RE (2008). The Encyclopedia of Fruit and Nuts. CABI Publishing, p. 954.

Lee CL, Paul JL, Hackett WP (1977). Promoting of rooting in stem cuttings of several ornamental plants by pretreatment with acid or base. HortScience 12:41-42.

Nanda KK (1975) Physiology of adventitious root formation. Indian Journal Plant Physiology 18:80-89.

Ortiz PL, Arista M, Talavera S (1995). Germination ecology of Ceratonia siliqua L. (Ceasalpinaceae), a Mediterranean tree. Flora 190:89-95.

Paul R, Aditi CH (2009). IBA and NAA of 1000 ppm induce more improved rooting characters in air-layers of waterapple (Syzygium javanica L.). Bulgarian Journal of Agricultural Science 15(2):123-128.

Pio R, Dall'Orto FAC, Alvarenga AA, Abrahao E, Chagas EA, Signorini G (2007). Propagation of 'Japones' quince for cutting and air layering. Ciencia Agrotecnologia 31(2):570574.

Romano A, Barros S, Martins-Loucao MA (2002). Micropropagation of the Mediterranean tree Ceratonia siliqua. Plant Cell Tissue Organ Culture 68:35-41.

Sahin U, Anapali O, Ercisli S (2002). Physicochemical and physical properties of some substrates used in horticulture, Gartenbauwissenschaft 67(2):55-60.

Sasso SAZ, Citadin I, Danner MA (2010). Propagation of Jabuticaba tree for grafting and air layering techniques. Revista Brasileira de Fruticultura 32(2):571-576. 